Medieval Archaeology. Vol. 64, no. 1 (Pre-proof, after-review edited version)

\title{
Mass production and mountain marketplaces in Norway in the Viking and Middle Ages
}

By Kjetil Loftsgarden

The Museum of Cultural History, University of Oslo

As hubs in stable economic networks the mountain marketplaces are seen as integral to the increase and eventual mass production of iron in the Viking and Middle Ages. The amounts of iron produced in this period exceeded local, regional and national demands, and iron constituted a valuable commodity from the inlands of Norway and Sweden.

This paper shows a dynamic trade network - one that was adaptable to trade patterns and surplus production. The marketplaces enabled an inland population to obtain the products they needed or wanted and the populous communities along the coast - the medieval towns, the royal and ecclesiastical elites - access to the resources and commodities from the hinterland via trade networks flowing through these marketplaces. This integration of the inland resources in the domestic and international economy can be considered as part of a functioning market economy in the western Scandinavian inland from the Late Viking Age.

Kjetil Loftsgarden, Ph.D., M.A.

The Museum of Cultural History, University of Oslo

Postboks 6762, St. Olavs plass, N - 0130 Oslo

Tlf. +47 22851902 Mobile +47 99020042

kjetil.loftsgarden@khm.uio.no 
The period from the Late Viking Age to the High Middle Ages (c. 950-1350), was one of economic expansion in Scandinavia: Towns where formed, populations increased, and royal and church power were firmly established. ${ }^{1}$ Even if the inland economy and resources have hardly been integrated into more overarching research, this paper highlights that these changes were also felt in inland Norway. This first systematic study of trade and exchange between the inland regions of South Norway and the coastal areas will be both applicable and relevant beyond Norway by furthering our understanding of Scandinavian resources and their role in the complex economic networks of this period.

Many of the well-known commodities from Scandinavia in the Viking and Middle Ages are non-agrarian products, such as furs, hides, ivory, antlers, soapstone vessels, honingstones and iron. These originate from areas beyond the arable land, a part of the landscape defined in Scandinavia as 'utmark' - the outfield. ${ }^{2}$ The primary geographical area of research is the inland of southern Norway, and in particular the areas surrounding the mountain plateau of Hardangervidda, see FIG 1. These are regions characterised by vast outfield areas, sparse arable land and relatively harsh in climate. The population density was low compared to the settlements in the lowlands. ${ }^{3}$ However, the inland seems to have been more independent, with a higher degree of selfowned farms and significantly lower tax burden. ${ }^{4}$

Earlier research has shown (1) an extensive surplus production in the inland regions of Norway and Sweden based on outfield resources such as iron from bog ore and products from hunting and trapping. ${ }^{5}$ And (2) large-scale trade and economic activities at marketplaces along the coast in the Viking Age, and in the medieval towns. ${ }^{6}$ So far, these two research strands are not fully integrated, and a major question remains

1 Glørstad and Loftsgarden 2017; Skre 2012; Brink and Price 2008; Helle et al. 2006; Andersson et al. 2008

${ }^{2}$ Holm et al. 2005

${ }^{3}$ Dyrvik 2004

${ }^{4}$ KLNM XV:539-541 Dørum 2004

${ }^{5}$ Larsen 2009; Rundberget 2013; Bergstøl 2008; Mikkelsen 1994; Tveiten 2012; Englund 2002; Magnusson 1986

${ }^{6}$ Skre 2007; Skre 2008; Skre 2011; Clarke and Ambrosiani 1991; Sindbæk 2007a; Bill and Rødsrud 2017; Pestell et al. 2003; Helle et al. 2006; Hansen 2017 
Medieval Archaeology. Vol. 64, no. 1 (Pre-proof, after-review edited version)

unanswered: How were the inland resources integrated in the domestic and international economy? In order to address this issue, we need to understand (1) the basic infrastructure of domestic trade - (2) what were the resources and commodities included in the trade and not least, (3) what were the rationale of the actors involved.

Building on previous research, ${ }^{7}$ this paper shows a dynamic trade network-one that was adaptable to trade patterns and surplus production-covering large parts of South Norway. In addition, I will explore the actors behind the surplus production from outfield resources and the subsequent trade with these commodities. Who were they and what caused them to start this extensive inland production and trade from late Viking Age (c.950-1050).

${ }^{7}$ Loftsgarden 2017 


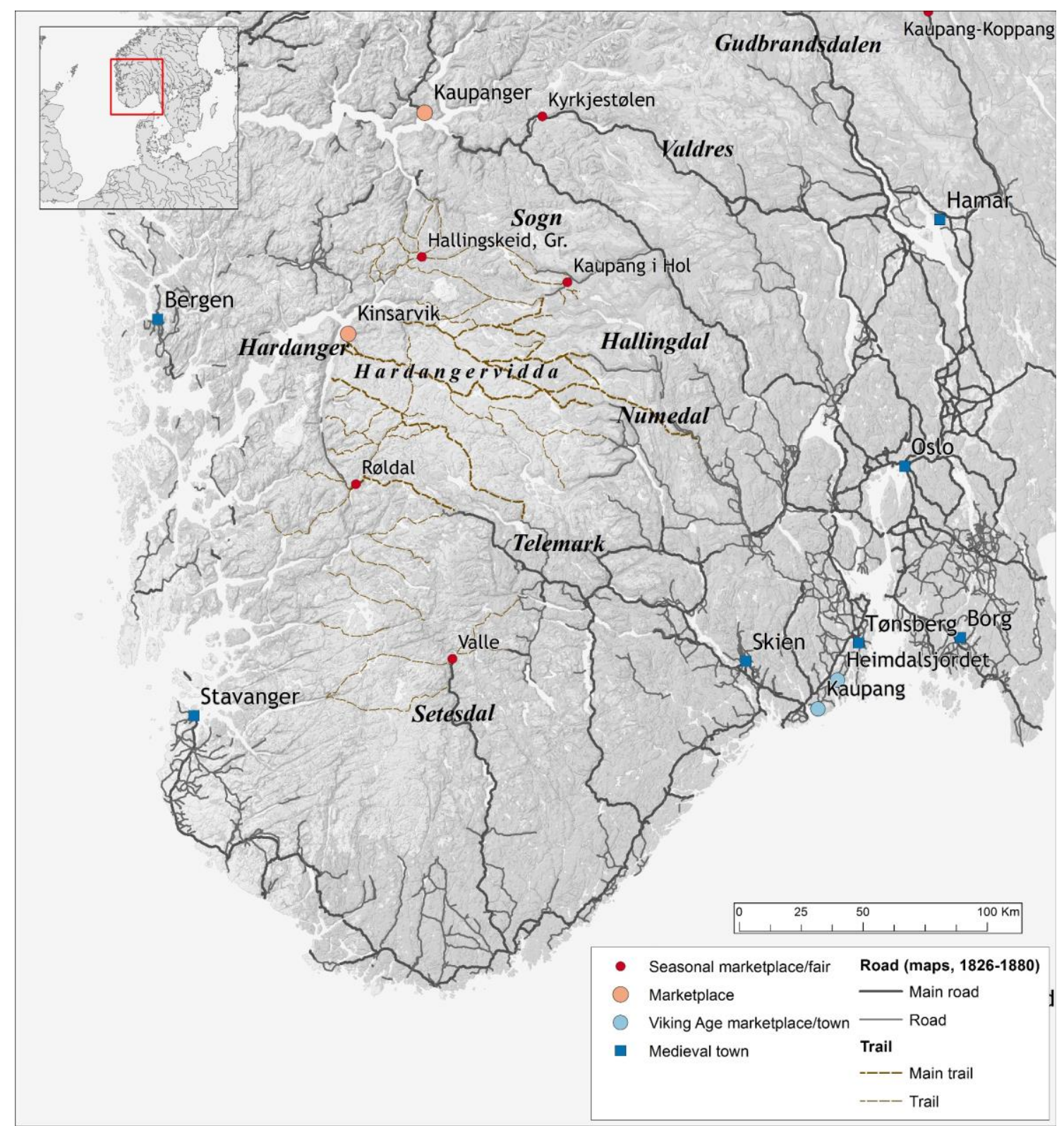

FIG 1: Places of trade in the regions surrounding the Hardangervidda-plateau and the main communication routes. Map by K. Loftsgarden. Background map: Kartverket (Norwegian Mapping Authority).

In terms of structure, the paper starts by identifying the inland marketplaces, their locations and range in size and activities. Subsequently I will explore the commodities that were part of the trade at the marketplaces-however, the focus is on iron. Iron production is especially visible in the archaeological material and are used as an example of the surplus production based on outfield resources in the inland regions. I will present calculations and show the extent of iron production in the Viking and Middle Ages. In the last part of the paper, my results are integrated in the ongoing 
Medieval Archaeology. Vol. 64, no. 1 (Pre-proof, after-review edited version)

discussion concerning marketplaces, trade and specialised surplus production in Scandinavia in the Viking Age and Middle Ages. I postulate that the marketplaces - as hubs in stable economic networks - was integral to the increase and subsequent mass production of iron. Moreover, I argue that the medieval towns, the royal and ecclesiastical elites were dependent on trade through these inland marketplaces.

\section{Data sources and methodical approaches}

When seeking to expand our knowledge of trade, marketplaces and inland surplus production one is dependent on utilising and triangulating information from a wide range of written, geographical and archaeological sources, see table 1. This is essential as few marketplaces have been excavated and the existing archaeological data material is scarce and often fragmented. As a result, the paper approaches the topic from three different angles; first by identifying the markets places, then calculating the iron production and lastly mapping the relations between marketplaces and sites of resource exploitation.

Table 1. The main sources used

Archaeological databases

Description

\begin{tabular}{l|l} 
Unimus.no & A near complete database containing
\end{tabular} Norwegian archaeological artefacts and samples

Askeladden.ra.no

A database with detailed information of Norwegian archaeological sites and monuments

Fornsok.se

A database with detailed information of Swedish archaeological sites and monuments

Kulturarv.dk/fundogfortidsminder/

Databases with detailed information of

Danish archaeological sites and monuments

\section{Written sources}

- Diplomatarium Norvegicum. Oldbreve til Kundskab om Norges indre og ydre Forhold, Sprog, Slagter, Sader, Lovgivning og Rettergang i Middelalderen.

Documents and letters from Norway older than 1590, verbatim and in the original language.

- Regesta Norvegica. kronologisk Fortegnelse over Dokumenter vedkommende Norge, Nordmand og den norske Kirkeprovins.
A chronological inventory of all known documents relating to the history of Norway during the Middle Ages. The series contains summaries in modern Norwegian of medieval documents concerning Norway and Norwegian affairs 


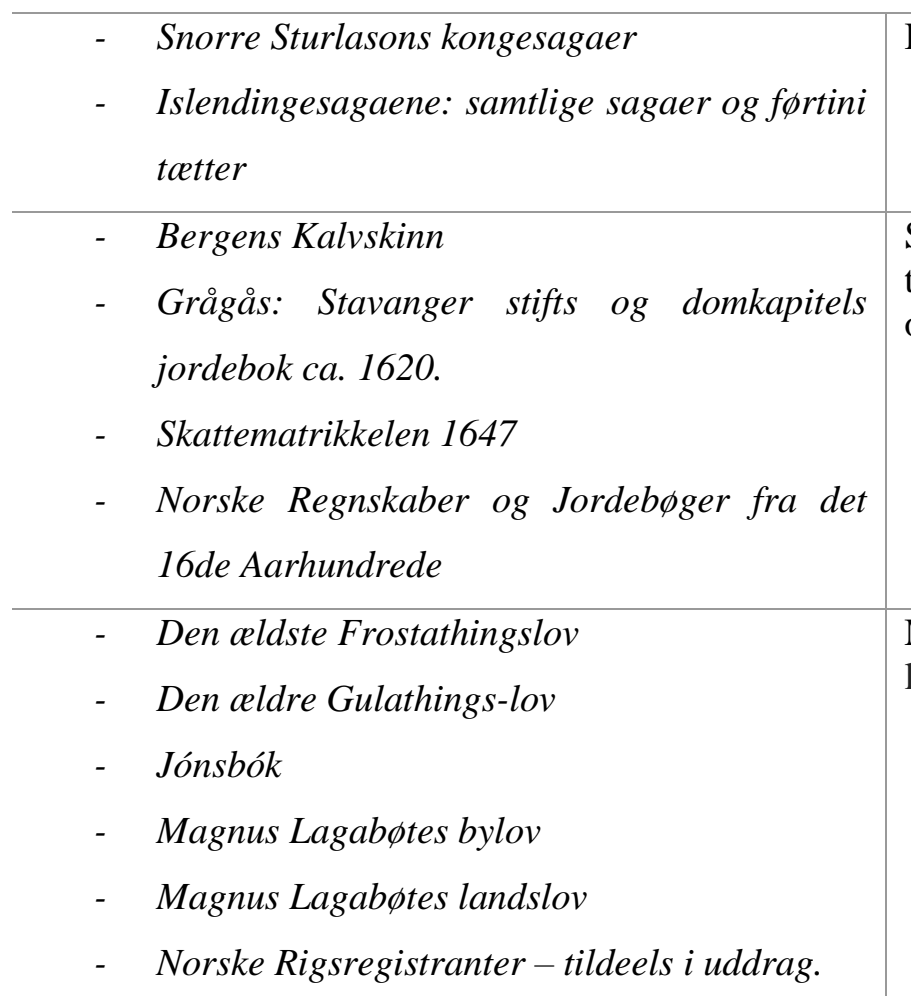

Historia Norwegie

Icelandic sagas

Surveys and registers for ownership and taxation purposes, such as the land-tax paid on a fixed assessment.

Medieval law texts and amendments to the law code

\section{Place names}

- Fritzner, Johan 1886-1896: Ordbog over det gamle norske Sprog, vol. I-III. Den norske Forlagsforening, Kristiania.

- Rygh, Oluf 1897-1924: Norske Gaardnavne oplysninger samlede til brug ved matrikelens revision. Bind I-XVIII. Christiania.

A brief history of Norway and a geographical survey, as well as a genealogy of the Earls of Orkney and a catalogue of the Kings of Norway. Written c. 1150-1200 AD.

Dictionary from Old Norse to Norwegian, the largest dictionary of its kind.

The work contains information such as the earliest record and the historical writing for the names of main farms (matrikkelgårder) in Norway.

- The Norwegian Mapping Authority, historical maps;

https://www.kartverket.no/kart/historiskekart/

\section{Local legends and traditions}

- Haukenæs, Thrond Sjursen 1884-1890: Folketro i Hardanger : belyst ved Natur- og Folkelivsskildringer, Eventyr, Sagn, Fortallinger osv. fra aldre og nyere tid. Bind I-XI.

- Solheim, Svale 1952: Norsk satertradisjon. Instituttet for sammenlignende kulturforskning. Serie B, vol. XLVII. Novus, Oslo.

A database containing most Norwegian maps older than 1900 . This includes military maps and the so-called "Amtskart" (1826-1917) which were the first detailed set of maps to cover all of Norway. 
Medieval Archaeology. Vol. 64, no. 1 (Pre-proof, after-review edited version)

\section{Identifying markets places}

In order to identify the marketplaces, I use a wide spectrum of available sources, see table 1. A number of place-names refer to old marketplaces or fairs, such as variations of the Old Norse kaup - the best-known example being Kaupang in Skiringssal. ${ }^{8}$ In addition, local traditions and legends may be helpful in locating marketplaces. The main body of data is nevertheless from surveys and re-examinations of existing archaeological and historical material.

Archaeologically, an identifying feature of marketplaces are concentrations of so-called token-money (e.g. coins, cut-up silver/gold) or equipment related to tokenmoney (e.g. scales, weights, weight-adjusted items). In Scandinavia these first appear in the Migration Period (AD 400-550) and subsequently in the Viking Age (AD 8001050). ${ }^{9}$ Especially from the $9^{\text {th }}$ and $10^{\text {th }}$ centuries, monetisation seems to become an integral part of wide scale trade. In this period there is a marked increase in regional surplus production, weights become standardised and there are indications of a greater use of silver as a means of payment. ${ }^{10}$

In some inland areas this monetisation can be seen in from of grave goods such as silver coins, imported goods and weighing equipment. In the context of being grave goods one can't equate this directly as traces of a marketplace. However, concentrations of graves containing coins, whole and fragmented, and weighing equipment indicates the importance of trade in a given region.

Minor excavations have been carried out as part of this project, and in collaboration with the Norwegian Institute for Cultural Heritage Research (NIKU), an area in Kinsarvik by the Hardangerfjord was mapped using ground-penetrating radar. ${ }^{11}$ Surveys conducted on marketplaces in mountainous regions found traces of tent rings, horseshoes, horseshoe nails, fire steel and knives-items that could represent traces of yearly gatherings with the purpose for trade, competition and social interaction.

\footnotetext{
${ }^{8}$ Schmidt 2000

${ }^{9}$ Skre 2017,284

${ }^{10}$ Pedersen 2008; Skre 2013,80-81

${ }^{11}$ Kristiansen et al. 2016
} 
Medieval Archaeology. Vol. 64, no. 1 (Pre-proof, after-review edited version)

\section{Resources - calculating the iron production}

Although a number of non-agrarian products from the inland were of importance as traded goods, see FIG 2, I will focus on iron. Numerous iron production sites have been surveyed and excavated, mainly due to the construction of dams as part of hydroelectric power and the development of large inland areas for cabins and cottages. ${ }^{12}$ The amount and quality of archaeological data from iron production is therefore especially good, and in this study, I use iron as an example of the surplus production of inland resources.

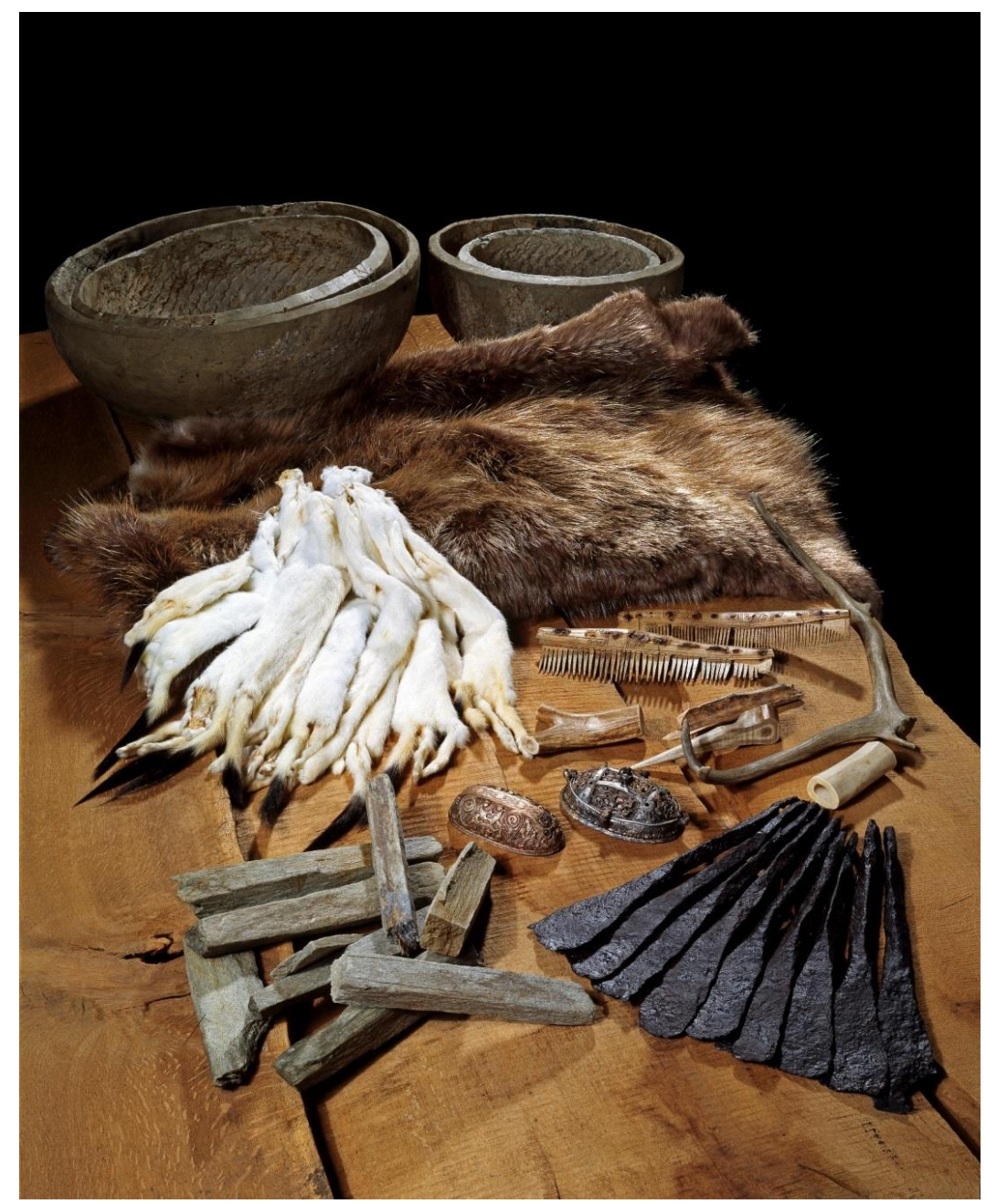

FIG 2: Examples of trade goods important in the Viking Age and Middle Ages in South Norway: soapstone vessels, fur, skins, antlers, honing stones and iron. Photo: I.E. Johnsen () The Museum of Cultural History, UiO / CC BY-SA 4.0

${ }^{12}$ Larsen 2009 
Iron production from bog ore is known in Scandinavia from the Early Iron Age up to the end of the Middle Ages. ${ }^{13}$ The technology of iron production, used in the Scandinavian Viking Age, was gradually introduced during the $7^{\text {th }}$ and $8^{\text {th }}$ centuries AD. Larger furnaces with slag pits were over time replaced with smaller and less resourceintensive furnaces with slag tapping. ${ }^{14}$

From the late $10^{\text {th }}$ century and onwards there is a marked increase in the iron production in South Norway, as well as in Sweden. ${ }^{15}$ The intensity of iron production is apparent from the thousands of production sites recorded, where the majority is dated to the period c. $1000-1300 .^{16}$

Based on metallurgical analysis it is possible to estimate the amount of iron produced on any given iron production site based on the amount of slag left behind on the site. ${ }^{17}$ To establish the total amount of iron produced I base my calculations on an average of three tons of slag per iron production site and interpolate from areas that are well surveyed by county archaeologists. While I estimate the demand for iron on a local, regional and national level by synthesising previous research. In addition, I recalibrate earlier C-14-results from iron production sites and charcoal pits, and in order to increase the accuracy of the data, I also carry out statistical analysis of C-14-results from previous excavations and projects. ${ }^{18}$

\section{Mapping spatial relations between marketplaces and sites of resource exploitation}

In order to map spatial relations between the marketplaces and sites for resource exploitation I use Geographic Information Systems (GIS). Digital information of the location and date of most archaeological finds, sites and monuments in Scandinavia are available in various databases, see table 1 . In addition, I utilise data from historical sources, place names and topographical elements. Moreover, communication routes are

\footnotetext{
${ }^{13}$ Stenvik 2003

${ }^{14}$ Nørbach 1999,245; Larsen 2009,95

15 Tveiten and Loftsgarden 2017

${ }^{16}$ Larsen 2009,181-183

${ }^{17}$ Rundberget 2007,333

${ }^{18}$ Using the OxCal calibration software, developed and run by The Oxford Radiocarbon Accelerator Unit at the University of Oxford.
} 
Medieval Archaeology. Vol. 64, no. 1 (Pre-proof, after-review edited version)

mapped in GIS from historical maps, mainly dated to the $18^{\text {th }}$ and $19^{\text {th }}$ century. Studies show that there exists a high correspondence between routes and roads from the Viking and Medieval Periods and those of the Modern Era. ${ }^{19}$ The abundance of data requires a systematic approach. This is achieved by storing both spatial and non-spatial data in a geodatabase, which also simplifies the development of analyses and queries.

\section{Results}

From the data and methods described, it is possible to establish a comprehensive overview of places of trade in the Southern Norwegian inland in the Late Viking Age to High Middle Ages and estimate the total amount of iron produced during this period. Together, this provides new and important knowledge regarding the utilisation of inland resources and the economic development in agriculturally marginal areas.

\section{Marketplaces}

By using the methods and material outlined above, I define and map 22 places of trade. This paper will focus on the smaller annual mountain marketplaces/fairs and the larger, more permanent marketplaces in the fjords (where the populations may have specialised partly in trade and crafts), see FIG 3.

${ }^{19}$ Steen 1929,211; Fønnebø 1988; Roland 2001; Sanmark 2009,210 


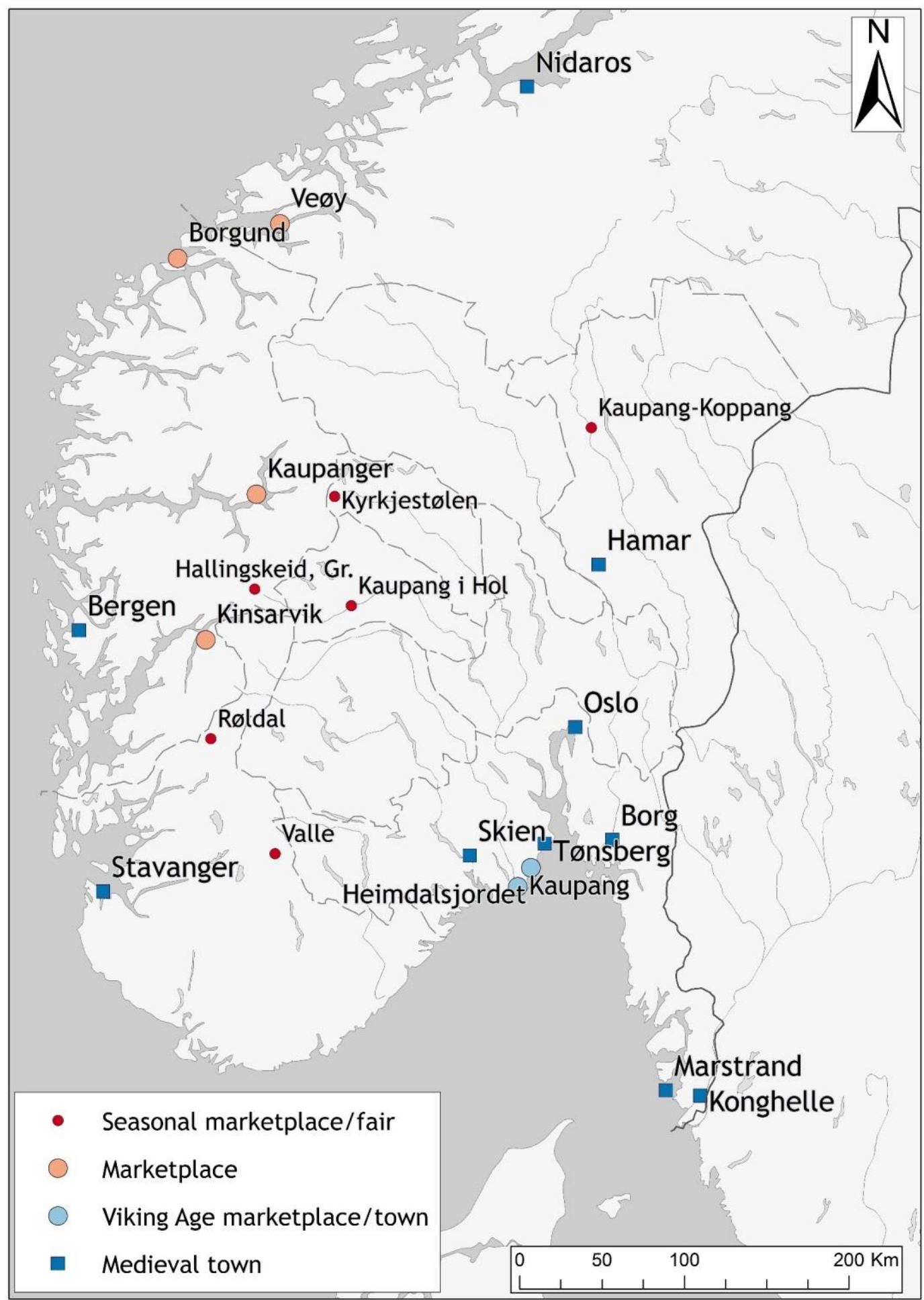

FIG 3: Map showing marketplaces and towns in South Norway c. 950 - 1350. Map by K. Loftsgarden. 
Medieval Archaeology. Vol. 64, no. 1 (Pre-proof, after-review edited version)

The degree of certainty for the identifications of the mountain and inland marketplaces varies between the sites. Obviously, the certainty increases with the size of the sites. The larger permanent marketplaces have thick cultural layers, waste from production and traces of buildings. The seasonal marketplaces are identified with the least degree of certainty and identifications are reliant on stray finds, place-names and local traditions.

Several of the inland marketplaces were located where fjords and mountains meet, or where paths and routes from different valleys converge. Many of the marketplaces also lie in boundaries between regions that exploited different resources.

Kaupanger in the inner parts of Sognefjorden, Veøy in the Romsdalsfjord and Borgund in Sunnmøre are the most prominent marketplaces, referred to as 'kaupangr' and 'kaupstaðr', between Bergen and Trondheim in the Late Viking Age to the High Middle Ages. ${ }^{20}$ At least from the $12^{\text {th }}$ century these three sites appear as marketplaces with a specialised population of traders and craftspeople, see FIG 3. They are also tied by economic and political networks to the medieval town Bergen, which experienced an increase in political and economic significance during this period. ${ }^{21}$

New geophysical surveys and a re-examination of archaeological excavations and finds suggest that Kinsarvik should be counted as a similar marketplace, although somewhat smaller. There are traces of 18-20 houses situated near the medieval stone church. ${ }^{22}$ This area also contains a thick cultural layer and finds of coins, slag, iron bars, fragments of soapstone vessels and ceramics; all of which indicate trade and possibly production in the Middle Ages. ${ }^{23}$

As detailed in FIG 3 and table 2, the results outline a development where marketplaces - both the larger/permanent sites with crafts and trade, and the smaller seasonal marketplaces - emerged in the inland areas of Norway and were in use from the Late Viking Age and throughout the High Middle Ages.

It can be difficult to date the period of use when researching places of trade, as there are few archaeological and historical sources, especially for the smaller sites. The

\footnotetext{
${ }^{20}$ Herteig 1954; Herteig 1974; Solli 1999; Øye 1989

${ }^{21}$ Helle 1982

${ }^{22}$ Kristiansen et al. 2016; Herteig 1968

${ }^{23}$ Loftsgarden 2017,92-106
} 
Medieval Archaeology. Vol. 64, no. 1 (Pre-proof, after-review edited version)

evidence of use concerning small and medium-sized places of trade in the periods

before the High Middle Ages must in many cases be regarded as circumstantial.

Table 2. An overview of the central marketplaces and potential seasonal marketplaces/fairs in

Southern Norway c. $950-1350$.

\begin{tabular}{|c|c|c|}
\hline Name & Assessment & Type \\
\hline Borgund & $\begin{array}{l}\text { Archaeological excavations have shown a largescale } \\
\text { marketplace with specialised trade and production. }{ }^{24} \\
\text { Borgund is also described in contemporary historical } \\
\text { sources. }{ }^{25}\end{array}$ & Marketplace \\
\hline Kaupanger & $\begin{array}{l}\text { Kaupanger is described as a major marketplace with } \\
\text { specialised tradespeople in the } 12^{\text {th }} \text { century Sverris } \\
\text { saga. }{ }^{26} \text { Archaeological excavations have shown } \\
\text { production sites connected to smithing, charcoal } \\
\text { production and the production of tar. }{ }^{27}\end{array}$ & Marketplace \\
\hline Kinsarvik & $\begin{array}{l}\text { Archaeological surveys have shown thick cultural } \\
\text { layers with charcoal, slag, an iron bar hoard, early } \\
\text { medieval silver coins and remains of soapstone } \\
\text { vessels. }^{28} \text { In addition, geophysical surveys have } \\
\text { shown several house remains that should be seen in } \\
\text { relation to trade and production. }{ }^{29}\end{array}$ & Marketplace \\
\hline$V e \phi y$ & $\begin{array}{l}\text { In } 12^{\text {th }} \text { century saga of Magnus Erlingsson, people } \\
\text { from Veøy are described as townspeople } \\
\text { (beyarmonnum). }{ }^{30} \text { Moreover, in the Böglunga sögur } \\
\text { (ch. 9), Veøy itself is described as a town (bainn). } \\
\text { Archaeological excavations have shown thick } \\
\text { cultural layers with slag from smithing, ceramics and } \\
\text { fragments of soapstone. }{ }^{31}\end{array}$ & Marketplace \\
\hline Kyrkjestфlen & $\begin{array}{l}\text { Kyrkjestølen is located in the mountains between } \\
\text { eastern and western parts of Southern Norway, } \\
\text { several kilometres from the nearest farmsteads. } \\
\text { Historical sources describe a seasonal } \\
\text { marketplace/fair at least from the } 17^{\text {th }} \text { century. }{ }^{32} \mathrm{~A}\end{array}$ & $\begin{array}{c}\text { Seasonal } \\
\text { marketplace/fair }\end{array}$ \\
\hline
\end{tabular}

${ }^{24}$ Herteig 1974; Myrvoll 1977; Larsen 1970

${ }^{25}$ NgL III:222-223; RN VII, nr 1191

${ }^{26}$ Sverris saga ch. $79-82$

${ }^{27}$ Øye 1989; Knagenhjelm 2004; Øye 1977

${ }^{28}$ Herteig 1968; Bakka 1954

${ }^{29}$ Kristiansen et al. 2016

${ }^{30}$ Sagaen om Magnus Erlingsson ch. 7-8

${ }^{31}$ Solli and Stamnes 2013; Solli 1999; Herteig 1954

${ }^{32}$ Ey 1916; Ruge 1916 [1750]; Øverland 1891 


\begin{tabular}{|c|c|c|}
\hline & $\begin{array}{l}\text { stave church built in the middle of the } 13^{\text {th }} \text { century } \\
\text { indicates the existence of a seasonal market place } \\
\text { also in the Middle Ages. }{ }^{33}\end{array}$ & \\
\hline Kaupang-Koppang & $\begin{array}{l}\text { The site is located on a small island in the river } \\
\text { Glomma with remains of a medieval church, as well } \\
\text { as cultural layers with findings from the Viking Age } \\
\text { to the Middle Ages including Viking Age weights. }{ }^{34} \\
\text { More archaeological investigations are needed; } \\
\text { however, the location, the findings and the place } \\
\text { names suggest a seasonal marketplace from the } \\
\text { Viking Age to the Middle Ages. }\end{array}$ & $\begin{array}{c}\text { Seasonal } \\
\text { marketplace/fair }\end{array}$ \\
\hline Røldal & $\begin{array}{l}\text { There are descriptions of a seemingly well- } \\
\text { established seasonal marketplace/fair from the } 17 \text { th } \\
\text { century. }{ }^{35} \text { Røldal is centrally located between the } \\
\text { inland and coastal regions and a relatively large } \\
\text { grave field indicates that Røldal had a regionally } \\
\text { central role in the Late Iron Age. }{ }^{36} \text { A finding of a } \\
\text { pair of scales from the Viking Age suggest that trade } \\
\text { was of importance, since there are few known scales } \\
\text { and weighing equipment in the Southern Norwegian } \\
\text { inland from this period. }{ }^{37}\end{array}$ & $\begin{array}{l}\text { Seasonal } \\
\text { marketplace/fair }\end{array}$ \\
\hline Valle & $\begin{array}{l}\text { There are several seasonal marketplaces/fairs in this } \\
\text { area, at least from the } 17 \text { th century. }{ }^{38} \text { Valle and the } \\
\text { nearby areas in Setesdalen stand out in the } \\
\text { Norwegian inland with several finds of weighing } \\
\text { equipment and hacksilver from Late Viking Age } \\
\text { graves. }{ }^{39} \text { This and the location as a connecting point } \\
\text { between inland and coastal areas, indicates the } \\
\text { importance of trade from the Late Viking Age and } \\
\text { onwards. }\end{array}$ & $\begin{array}{c}\text { Seasonal } \\
\text { marketplace/fair }\end{array}$ \\
\hline $\begin{array}{l}\text { Hallingskeid in } \\
\text { Grфndalen }\end{array}$ & $\begin{array}{l}\text { The site is located in the mountains where several } \\
\text { known paths meet. }{ }^{40} \text { The place name, the location, } \\
\text { traditions and stray finds of horseshoes, horseshoe- } \\
\text { nails and knives indicates a seasonal marketplace/fair } \\
\text { in the Middle Ages. }{ }^{41}\end{array}$ & $\begin{array}{l}\text { Seasonal } \\
\text { marketplace/fair }\end{array}$ \\
\hline
\end{tabular}

\footnotetext{
${ }^{33}$ Christie et al. 2013

34 (Mus.nr. C52727/9-11)

${ }^{35}$ Haukenæs 1894,349; Dalen and Dalen 1960,152

${ }^{36}$ Kraft 1830,680-681; Fett 1955,4-7

${ }^{37}$ Museum number B6718/C235871

${ }^{38}$ Gjellebøl 1800,55-58; Glostrup and Huitfeldt-Kaas 1895,39

${ }^{39}$ Larsen 1980; Glørstad and Wenn 2017

${ }^{40}$ Vallevik 1961

${ }^{41}$ Loftsgarden et al. 2017; Berg et al. 2017
} 


\begin{tabular}{l|l|c}
\hline Kaupang in Hol & $\begin{array}{l}\text { The place name and the location where three valleys } \\
\text { and routes meet indicate a seasonal marketplace/fair, } \\
\text { however further archaeological investigations are } \\
\text { needed. }\end{array}$ & $\begin{array}{c}\text { Seasonal } \\
\text { marketplace/fair }\end{array}$
\end{tabular}

\section{Iron production c. AD 950-1350}

Charcoal pits are closely connected to iron production in Norway in the Viking and Middle Ages. ${ }^{42}$ By analysing the distribution of charcoal pits, it is therefore possible to differentiate between the distribution of slag-tapping furnaces used in the Viking Age and the Middle Ages from the earlier iron production sites, and consequently indicate the core areas of iron production in this period. As shown in FIG 4, this equates to the upper parts of the main valleys of South Norway, namely Setesdal, Telemark, Hallingdal and Valdres, and the middle part of Østerdalen.

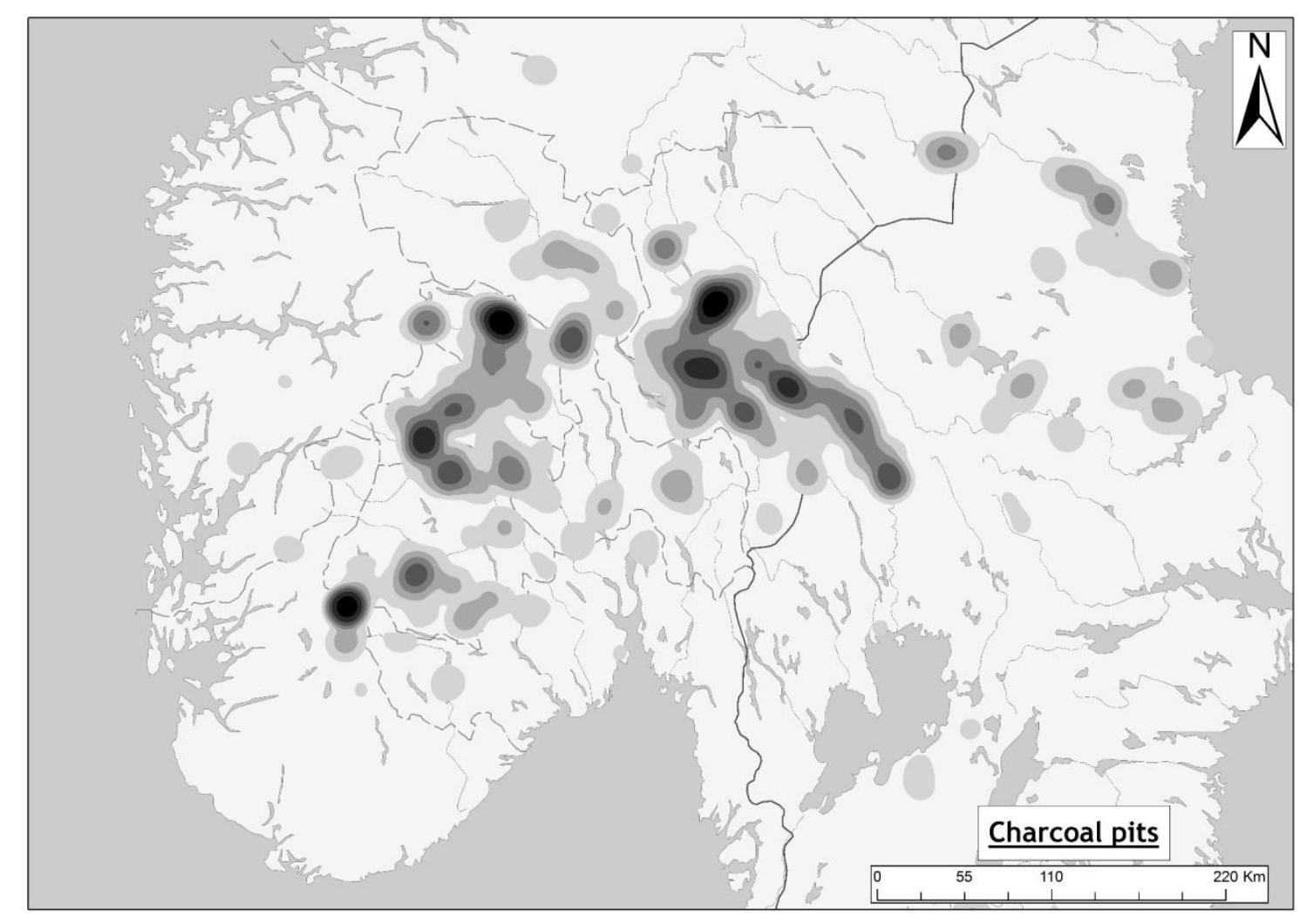

FIG 4: Kernel density map showing the distribution of known charcoal pits (32,668 pits), indicating iron production sites in the Viking Age and the Middle Ages, $10^{\text {th }}$ to $14^{\text {th }}$ century, in Norway and Sweden. Data from the Norwegian database for cultural heritage, Askeladden, and

${ }^{42}$ Bloch-Nakkerud 1987; Loftsgarden 2015 
Medieval Archaeology. Vol. 64, no. 1 (Pre-proof, after-review edited version)

the Swedish National Heritage Board's database for archaeological sites and monuments, Fornsök. Map by K. Loftsgarden.

Calculations based on surveyed and excavated iron production sites indicates that in South Norway as much as 190000 tonnes of iron were produced from the Late Viking Age and throughout the High Middle Ages. ${ }^{43}$ A summary of radiocarbon dates from charcoal pits using a kernel density approach show that iron production followed a curve of gradually increasing production from the end of the Viking Age and with a high activity over a period of around 300 years before the production declined somewhat rapidly beginning around $1250,{ }^{44}$ see FIG 5 .

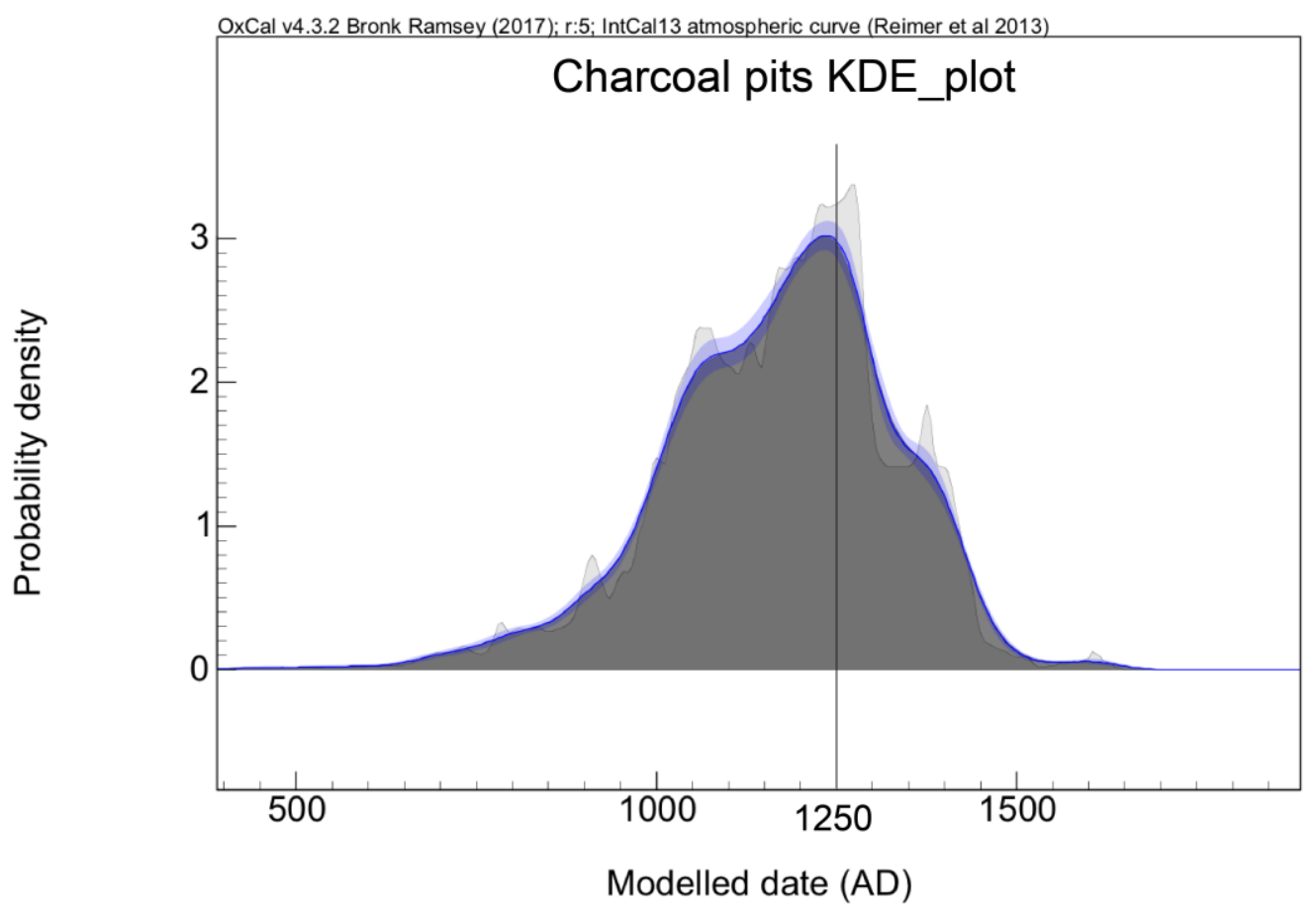

FIG 5: 1104 radiocarbon dates from excavated charcoal pits in South Norway summarized using a kernel density approach in OxCal. ${ }^{45}$ The dates are collected by professor Jan Henning Larsen and Kjetil Loftsgarden.

\footnotetext{
${ }^{43}$ Loftsgarden 2017,69; Rundberget 2013,253-254

${ }^{44}$ Loftsgarden 2017,69

${ }^{45}$ See Ramsey 2017
} 
Medieval Archaeology. Vol. 64, no. 1 (Pre-proof, after-review edited version)

\section{Supply and demand}

The estimate of 190,000 tonnes of iron produced from the Late Viking Age to the High Middle Ages in Norway is significantly higher than the estimates made of the demand for iron during this period. Hans Andersson, Gitte Hansen and Sonia Jeffrey have presented an estimate of iron consumption in medieval towns based on data from Bergen in Norway and Lödöse in Sweden. ${ }^{46}$ Studying the finds from the excavated areas of Bergen dated to approx. AD 1100-1170, they found that iron objects constituted a total weight of 3330 grams. The authors estimate that one would find around $82 \mathrm{~kg}$ if the entire town area was excavated. ${ }^{47}$ This would mean an iron consumption of barely $1.2 \mathrm{~kg}$ per year. For Lödöse their estimate is $3500 \mathrm{~kg}$ over 300 years, which equates to $12 \mathrm{~kg}$ per year. ${ }^{48}$ However, there are issues connected to methodology and representativeness, such as the preservation of iron, as the authors also recognise. In addition, the iron which forms the basis of the estimate, constitutes the iron that went out of circulation and not the iron used. ${ }^{49}$ Iron produced in this period was excellent for smithing and this made it relatively easy to forge larger items from smaller pieces. ${ }^{50}$ For example, studies of iron bars from the medieval town Tønsberg showed that most were welded together from smaller parts. ${ }^{51}$ This suggests that most iron was reused, and explains the small amounts of iron found in Middle Age towns. ${ }^{52}$

Based on Lödöse, a minimum amount of iron that went out of circulation in Swedish towns in the period 1000-1300 has been estimated to be a total of 52 tonnes. ${ }^{53}$ Catarina Karlsson on the other hand has estimated an annual loss of iron through wear in connection with soil cultivation alone to be around 48 tonnes per year in Sweden around $1300{ }^{54}$ This may indicate that in Sweden the greatest demand for iron was in

\footnotetext{
${ }^{46}$ Andersson et al. 2015

${ }^{47}$ Andersson et al. 2015,224

${ }^{48}$ Andersson et al. 2015,238

49 Andersson et al. 2015,225

${ }^{50}$ Granås 2015

${ }^{51}$ Jakobsen 1991,146

${ }^{52}$ As also pointed out by Hansen 2015,167-169

${ }^{53}$ Andersson et al. 2015,247

${ }^{54}$ Karlsson 2015,296
} 
Medieval Archaeology. Vol. 64, no. 1 (Pre-proof, after-review edited version)

rural areas. ${ }^{55}$ However, there has been little research on the iron requirements connected to monumental buildings, boat constructions and warfare in Scandinavian Viking and Middle Ages.

The annual demand for iron during the Middle Ages in Norway has been estimated at $1 \mathrm{~kg}$ per farm, although $5 \mathrm{~kg}$ is also used. ${ }^{56}$ In order to use these figures for the society as a whole, one must calculate the population size and the number of farms. It is estimated that the number of farms in Norway around 1300 was between 60,000 and 70,000, and a population size between 400,000 and 530,000. ${ }^{57}$

With an estimate of 60,000-70,000 farms and an annual demand of $1 \mathrm{~kg}$ iron per farm, a year's iron requirement around $\mathrm{AD} 1300$ will be of 60-70 tonnes. This corresponds well with the figure Karlsson has put forth from Sweden. Over a period of 300 years, there would have been a need of 18,000-21,000 tonnes of iron for all farms within Norway's modern borders. This figure may also be lower because the calculations do not consider the increase in the number of farms from the Late Viking Age. Nevertheless, this and previous estimates of iron demand are surprisingly low considering the estimates of the amount of iron produced. Even with a consumption of 5 $\mathrm{kg}$ of iron per farm per year, the annual demand does not exceed 300-350 tonnes of iron and 90,000-105,000 tonnes over 300 years. This indicates that the domestic demand for iron was significantly less than the supply. Consequently, iron from the Norwegian inland must have been a regional, interregional and international commodity in the period $1000-1300 \mathrm{AD}^{58}$

\section{Discussion}

This brings us back to the main questions set out above; what caused the extensive inland production and trade from the Late Viking Age and throughout the High Middle Ages? And how were inland resources integrated in the domestic and international economy?

\footnotetext{
55 Andersson et al. 2015,247

56 Bielenin 1976; Narmo 1997,128

${ }^{57}$ Sandnes and Salvesen 1978,58, 61; Lunden 2002,20; Øye 2002,252

${ }^{58}$ Loftsgarden 2017,71-72
} 
Medieval Archaeology. Vol. 64, no. 1 (Pre-proof, after-review edited version)

As shown, there were several marketplaces of varying size and complexity from the Late Viking Age and onwards, and in the same period there was a considerable regional surplus in the production of iron in the inland of Southern Norway. The location of the marketplaces and finds of iron bar hoards and iron slag suggest that iron, and other inland resources, were part of extensive trade networks where marketplaces functioned as hubs connecting the inland to the coast.

Dagfinn Skre has convincingly argued for the monetarisation of the Scandinavian societies, first in the Migration Period (in the $5^{\text {th }}$ to $6^{\text {th }}$ centuries AD) and then again in the Viking Age. ${ }^{59}$ Skre finds that once the monetary practices of valuing items in a common monetary unit and paying by means of a medium had been established, transaction could be monetary despite the absence of token-money, such as silver or coins. Consequently, the introduction of a monetary practice was a change in mind-set and not merely the introduction of a certain media. ${ }^{60}$

The results presented in this paper support this assertion and indicates that trade (the value of and payment for commodities) followed a monetary practice that had become well established by the Late Viking Age-not only in the populated coastal regions, but also at marketplaces/fairs in the inland areas. For instance, it is reasonable to assume that the findings of weighing equipment, silver coins and hacksilver from sevaral late pre-Christian burials (dated between 970-1065 AD) in Valle, Setesdalen, mentioned in table 2, reflect a greater resource specialisation and economic structuring of the society from the Late Viking Age - a development that may have occurred in large parts of South Norway, but which is most visible in the grave goods of the extraordinarily late pre-Christian burials in Setesdalen.

It is likely that monetarisation of society made surplus production and trade a viable economic option for the inland farmers. However, a key factor behind the increase in regional surplus production must have been that there was a demand for the goods the inland could produce. Consequently, one should see the extensive amounts of iron produced during this period in view of the increased demand for iron. Although this is likely to have changed slowly and over time, there were several technological changes in agriculture in Northern Europe in the period between AD 1000-1200 that

\footnotetext{
59 Skre 2017

${ }^{60}$ Skre 2017,283
} 
increased the demand. A central feature is the use of spades with an iron edging and larger, heavier ploughshares. ${ }^{61}$ Based on Swedish material, it appears that the weight of ard- and ploughshares remains stable between $0.3-0.5 \mathrm{~kg}$ from the $6^{\text {th }}$ century and up to the end of the $10^{\text {th }}$ century-at which point the shares became longer and the weight increased to about $1 \mathrm{~kg} .{ }^{62}$

Ploughshares were exposed to severe wear and tear, and accounts from the $16^{\text {th }}$ century Swedish royal manors and farms show that a ploughshare was worn down to half its size in four years. ${ }^{63}$ In Denmark, Jørgen Elsøe Jensen estimated that by the end of the $13^{\text {th }}$ century around 500 tonnes of iron were needed annually for ploughs alone. ${ }^{64}$ Only a handful of iron production sites from the Viking Age and the Middle Ages are so far known in Denmark, meaning they were dependant on iron import. ${ }^{65}$

There was a significant exchange of goods within Scandinavia from the Viking Age, exemplified by archaeological objects such as soapstone products, quernstones and reindeer antlers. ${ }^{66}$ It is reasonable to assume there also was a considerable degree of export of iron from Sweden and Norway to Denmark. There have been conducted trace analyses of iron and slag in iron found in Denmark to determine the origins of the iron. These, admittedly few analyses, show that at least some of the iron in Denmark came from Norway. ${ }^{67}$ This corresponds well to my results showing the considerable amounts of iron produced in Norway, which, as previously discussed, greatly exceeded local and national demands.

The demand for iron may well have been an important factor for farmers, based in the mountain and valley regions, in deciding whether to start iron production-at least in the sense that increased demand caused iron as a commodity to increase in value. This could have been a motivational factor to start production; even so, the value

\footnotetext{
${ }^{61}$ White 1964; Andersen et al. 2016

${ }^{62}$ Myrdal 1999,53

${ }^{63}$ Myrdal 1999,53

${ }^{64}$ Elsøe Jensen 2010,10

${ }^{65}$ Lyngstrøm 2008; Larsen 2009,193-194

${ }^{66}$ Baug 2015; Sindbæk 2005; Ashby et al. 2015

${ }^{67}$ Birkedahl 2000,35; Buchwald 2005; Lyngstrøm 2008; Rundberget 2015,178-182
} 
must have been high enough for farmers to risk using already stretched resources, such as time and labour, on iron production.

Iron was produced throughout the Iron Age but an increase in demand, and with that an increase in value, probably stimulated an increase in iron production. And it is likely that the idea of iron production, as a possible way of providing commodities for trade, spread from farm to farm and region to region over time-as Bernt Rundberget has shown was the case in $\emptyset_{\text {sterdalen. }}{ }^{68}$ Although iron production was a specialised skill, it was nevertheless an experience-based knowledge that, when first learned, was more labour-intensive than complicated. ${ }^{69}$

The technological changes that came about in Scandinavia towards the Viking Age did not make iron production more effective, but it did make iron production more dynamic. ${ }^{70}$ The introduction of charcoal pits meant that one could use smaller trees as fuel for the iron production and therefore marginal forest areas could be exploited. Thus, the less resource-intensive furnaces and the use of charcoal pits meant that iron production in the Viking Age and Middle Ages was well suited for low mountain areas and upper valley regions, and could easily be adapted to farms with a diverse economy of animal husbandry, agriculture and seasonal utilisation of outfield resources. ${ }^{71}$ The smaller and simpler iron production sites from the Late Iron Age and the Middle Ages could be readily established and then moved after a few seasons, closer to the sources of wood and ore. One was not dependant on investing a lot of time and resources on one site and iron production became more flexible and adaptable to economic and political changes.

The technological changes were undoubtedly important. However, the triggering factor for the surplus production of iron by farmers from the mountainous/valley districts at the end of the Viking Age was more likely linked to social structures. By this point in time, the social structures were stable enough to maintain trade networks between the marginal regions and the central, more populous areas over a longer period.

\footnotetext{
${ }^{68}$ Rundberget 2013,302-308

${ }^{69}$ Larsen and Mjærum 2014,116-117

70 Tveiten and Loftsgarden 2017

${ }^{71}$ Loftsgarden 2017,264; Orrman 2003,280
} 
Medieval Archaeology. Vol. 64, no. 1 (Pre-proof, after-review edited version)

The marketplaces thereby become an important intermediary space where resources from regional surplus production could become a commodity and all actors could be certain to exchange their goods against other desired and/or necessary products.

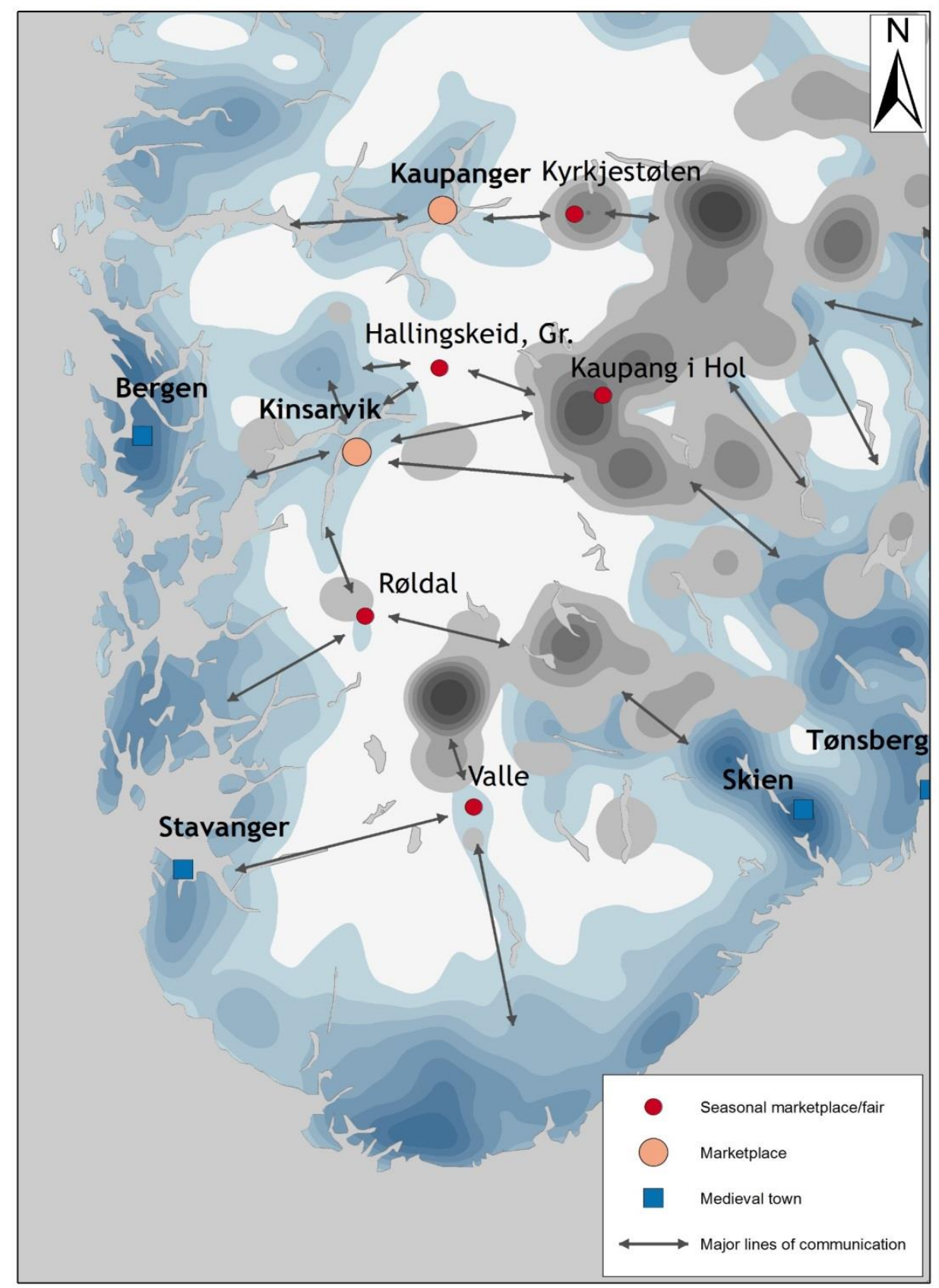

FIG 6: Kernel density map showing marketplaces and towns in relation to the major iron producing areas in the Viking Age and the Middle Ages in black/grey and areas of greatest population in blue. The population data is based on farmsteads shown on 19th century maps, "Amtskart", which have been digitalised as part of a project led by Professor Frode Iversen, the Museum of Cultural History, University of Oslo. Map by K. Loftsgarden. 
Medieval Archaeology. Vol. 64, no. 1 (Pre-proof, after-review edited version)

The driving force may have been that iron production was considered a secure and possibly lucrative subsistence strategy. Local and regional elites could also have worked to promote iron production, as well as the king and church. Still I consider it unlikely that outside forces were directly involved in the utilisation of resources, at least concerning the areas surrounding the Hardangervidda-plateau. This is unlikely because of the way iron production was organised - on thousands of small sites spread out over vast areas. In addition, the farms in these areas seems to have had a high degree of selfownership. ${ }^{72}$ As such, they were exempted from several taxes and there appear to be little direct involvement from the king before well into the High Middle Ages. ${ }^{73}$ Still, the king and church were gaining importance through economic and political networks that were vital for the emergence of marketplaces, especially of the larger permanent sites. $^{74}$

The location of the marketplaces/fairs indicates that they served as interregional meeting places between inland and coastal areas, see FIG 6. It may therefore be relevant to see the marketplaces as hubs in scale-free networks. ${ }^{75}$ Such a network was dependent on relatively few central hubs with many contacts that provided the connection between more marginal links in the network. This made it extremely effective, but also vulnerable and unstable in times of crisis, if key persons or sites should fall. ${ }^{76}$ As hubs in scale-free networks, the marketplaces enabled an efficient trading of goods and resources and made marketplaces an arena where specialised farmers could be confident that they could trade off their surplus production.

The changes in technology previously outlined meant that specialised farmers more easily could adjust the iron production to varying degrees of supply and demand. This was important since the specialised farmers on relatively marginal farms could not risk spending time and labour on producing large quantities of iron if they were not confident they could exchange the surplus iron for things they needed or wanted.

\footnotetext{
72 Bjørkvik and Holmsen 1972,71; Helle 1974,158; Loftsgarden 2017,225-227

${ }^{73}$ Steinnes 1930,141-142; Bjørkvik 1970

${ }^{74}$ Loftsgarden 2017,273-275

${ }^{75}$ Barabási and Albert 1999; Sindbæk 2007b

${ }^{76}$ Sindbæk 2007b,71
} 
Medieval Archaeology. Vol. 64, no. 1 (Pre-proof, after-review edited version)

I would argue it is likely that trade attained an increasing prominence on annual fairs in the mountain and valley regions from the Late Viking Age, in line with the monetisation and the growing regional specialisation and surplus production. As trade became more prominent, we can identify these meeting places as seasonal marketplaces. However, based on archaeological and historical sources, it is difficult to clearly distinguish between fairs and seasonal marketplaces. Such a distinction may also not be relevant, as it is likely that trade was a part of most social gatherings. ${ }^{77}$

\section{Conclusion}

This study has shown the existence of a broad range of marketplaces from the Late Viking Age to the High Middle Ages, spanning from seasonal marketplaces or fairs in mountainous regions to more established marketplaces with specialised trade- and craftspeople in inner fjord regions. As such, trade could take place on a number of sites and settings, differing both in size and in complexity.

Thousands of small-scale iron production sites in the inland, and a high-degree of self-ownership and reduced taxation in the same region, indicate that the extensive surplus production of iron was organised and carried out by specialised local farmers. The goods resulting from this surplus production could then be exchanged at seasonal marketplaces in the mountainous or upper valley districts, or at more permanent marketplaces like Kinsarvik in Hardanger or Kaupanger in Sogn.

Several factors were at play for this development to occur, but an important precondition was the monetisation of the Scandinavian societies and an increased demand for iron. The amounts of iron produced in Norway in this period exceeded local, regional and national demands for iron. Still, one can assume that iron was not produced in quantities that were difficult or impossible to be traded off. The value of iron must have outweighed the cost of production to such a degree that it became a viable resource for farmers in the inland regions.

At the marketplace, an inland population could obtain the products they needed or wanted and the populous communities along the coast - the medieval towns, the royal and ecclesiastical elites - had access to the resources from the hinterland via trade networks flowing through these marketplace hubs. This integration of the inland

${ }^{77}$ Brendalsmo et al. 2009; Loftsgarden et al. 2017 
Medieval Archaeology. Vol. 64, no. 1 (Pre-proof, after-review edited version)

resources in the domestic and international economy can be considered as part of a functioning market economy in the South Norwegian inland from the Late Viking Age.

The lack of iron production sites in Denmark indicates that this country was the recipient of a considerable amount of the iron produced in Norway. However, the international trade of iron is not fully understood and demands more research. Questions regarding who organised this trade, who were the tradespeople and who were the recipients are some of the questions that need to be addressed.

\section{Bibliography}

Andersen, T. B., Jensen, P. S. \& Skovsgaard, C. V. 2016. The heavy plow and the agricultural revolution in Medieval Europe. Journal of Development Economics, 118, 133-149.

Andersson, H., Hansen, G. \& Jeffery, S. 2015. Järn och städer. Tankar kring det arkeologiska materialet i Bergen och Gamla Lödöse. Järnet och Sveriges medeltida modernisering. Jernkontoret.

Andersson, H., Hansen, G. \& Øye, I. (eds.) 2008. De første 200 årene : nytt blikk på 27 skandinaviske middelalderbyer, Bergen: Universitetet i Bergen.

Ashby, S. P., Coutu, A. N. \& Sindbæk, S. M. 2015. Urban Networks and Arctic Outlands: Craft Specialists and Reindeer Antler in Viking Towns. European Journal of Archaeology, 18, 679-704.

Bakka, E. 1954. Mellomaldersfunn frå Kinsarvik. Bergens Tidende, 13.10.1954.

Barabási, A.-L. \& Albert, R. 1999. Emergence of Scaling in Random Networks. Science, 286, 509-512.

Baug, I. 2015. Quarrying in Western Norway: an archaeological study of production and distribution in the Viking period and the Middle Ages, Oxford, Archaeopress.

Berg, H., Granados, T. J. \& Loftsgarden, K. 2017. Rapport frå arkeologisk unders $ø$ king på Hallingskeid gbnr. 37/5. Buplass frå steinalder, kokegropfelt og mogleg skeid. Ulvik kommune, Hordaland. Upublisert rapport, Institutt for Arkeologi, Historie, Kultur- og Religionsvitskap, Universitetet i Bergen.

Bergstøl, J. 2008. Samer $i$ Østerdalen? : en studie av etnisitet $i$ jernalderen og middelalderen $i$ det nordøstre Hedmark. Upublisert doktorgradsavhandling i arkeologi, Universitet i Oslo.

Bielenin, K. 1976. Tidlig järnframställning i Polen. När järnet kom. Göteborg: Göteborgs Arkeologiske Museum.

Bill, J. \& Rødsrud, C. 2017. Heimdalsjordet - trade, production and communication. In: Glørstad, Z. T. \& Loftsgarden, K. (eds.) Viking-Age Transformations: Trade, Craft and Resources in Western Scandinavia. Routledge.

Birkedahl, P. 2000. Sebbersund - en handelsplads med trækirke ved Limfjorden forbindelser til Norge. Havn og handel i 1000 år: Karmфyseminaret 1997. Stavanger: Dreyer bok.

Bjørkvik, H. 1970. Skatter. In: Hødnebø, F. (ed.) KLNM XV. Oslo: Gyldendal. 
Bjørkvik, H. \& Holmsen, A. 1972. Kven åtte jorda i den gamle leiglendingstida? Fordelinga av jordeigedomen i Noreg i 1661, Trondheim, Tapir.

Bloch-Nakkerud, T. 1987. Kullgropen i jernvinna фverst $i$ Setesdal, Oslo, Universitetets Oldsaksamling.

Brendalsmo, J., Eliassen, F.-E. \& Gansum, T. 2009. Den Urbane underskog: strandsteder, utvekslingssteder og småbyer $i$ vikingtid, middelalder og tidlig nytid, Oslo, Novus forlag.

Brink, S. \& Price, N. S. (eds.) 2008. The Viking world, London: Routledge.

Buchwald, V. F. 2005. Iron and steel in ancient times, Copenhagen, Det Kongelige Danske Videnskabernes Selskab.

Christie, S., Storsletten, O. \& Hoff, A. M. 2013. St. Tomaskirken [Online]. Norgeskirker.no. Available: http://www.norgeskirker.no/wiki/St._Tomaskirken [Accessed 18.11. 2013].

Clarke, H. \& Ambrosiani, B. 1991. Towns in the Viking age, Leicester, Leicester University Press.

Dalen, K. \& Dalen, A. 1960. Røldal bygdebok, Røldal, Odda kommune.

Dyrvik, S. 2004. Befolkningsutvikling. Norsk historisk leksikon. www.lokalhistoriewiki.no: Cappelen forlag.

Dørum, K. 2004. Romerike og riksintegreringen : integreringen av Romerike $i$ det norske rikskongedфmmet $i$ perioden ca. 1000-1350. Upublisert doktorgradsavhandling i historie, Universitetet i Oslo.

Elsøe Jensen, J. 2010. Gensidig afhoengighed: en arv fra fortiden. Danmarks middelalderbyer - et vidnesbyrd om spredningen af vestlig civilisation, Odense, Syddansk universitetsforlag.

Englund, L.-E. 2002. Blästbruk: myrjärnshanteringens forändringer $i$ ett långtidsperspektiv, Stockholm, Jernkontoret.

Ey, T. 1916. Vang og Slire: Valdres, Los Angeles.

Fett, P. 1955. Røldal prestegjeld, Bergen, Universitetet i Bergen, Historisk Museum.

Fønnebø, R. 1988. Langs Nordmannsslepene over Hardangervidda, Oslo, Universitetsforlaget.

Gjellebøl, R. 1800. Beskrivelse over Sætersdalen i Christiansands Stift. Topographisk Journal For Norge, 26, 1-177.

Glostrup, N. \& Huitfeldt-Kaas, H. J. 1895. Biskop Nils Glostrups Visitatser i Oslo og Hamar Stifter 1617-1637, Christiania, Thronsen.

Glørstad, A. Z. \& Loftsgarden, K. (eds.) 2017. Viking-Age Transformations: Trade, Craft and Resources in Western Scandinavia: Routledge.

Glørstad, Z. T. \& Wenn, C. C. 2017. A view from the valley: Langeid in Setesdal, South-Norway - a Viking Age trade station along a mercantile highway In: Glørstad, Z. T. \& Loftsgarden, K. (eds.) Viking-Age Transformations: Trade, Craft and Resources in Western Scandinavia. Routledge.

Granås, T. 2015. Gjenbruk av jern. Upublisert rapport.

Hansen, G. 2015. After the Town Burned! Use and Reuse of Iron and Building Timber in a Medieval Town. In: Øye, I., Baug, I., Åstveit, J. \& Mygland, S. S. (eds.) Nordic Middle ages - artefacts, landscapes and society : essays in honour of Ingvild Øye on her 70th birthday.

Hansen, G. 2017. Domestic and exotic materials in early medieval Norwegian towns: an archaeological perspective on production, procurement and consumption. In: Glørstad, Z. T. \& Loftsgarden, K. (eds.) Viking-Age Transformations: Trade, Craft and Resources in Western Scandinavia. Routledge. 
Haukenæs, T. S. 1894. Strandebarm ; Hålandsdalen ; Røldal, Hardanger.

Helle, K. 1974. Norge blir en stat: 1130-1319, Bergen, Universitetsforlaget.

Helle, K. 1982. Kongssete og kjøpstad : fra opphavet til 1536, Bergen, Universitetsforlaget.

Helle, K., Eliassen, F.-E., Myhre, J. E. \& Stugu, O. S. 2006. Norsk byhistorie: urbanisering gjennom 1300 år, Oslo, Pax.

Herteig, A. E. 1954. Omkring Kaupangen på Veøy i Romsdal. Viking, XVIII, 69-88.

Herteig, A. E. 1968. Beretning om befaring av Kinsarvik almenning. Universitetet i Bergen, Historisk museum.

Herteig, A. E. 1974. Borgundkaupangen på Sunnmøre, Ålesund, Borgundkaupangens venner.

Holm, I., Innselset, S. M. \& Øye, I. (eds.) 2005. 'Utmark': the outfield as industry and ideology in the Iron Age and the Middle Ages, Bergen: University of Bergen.

Jakobsen, S. 1991. Hersker og smed: smedarbeider $i$ Tonsberg i perioden ca. 11501350, Tønsberg, Riksantikvaren.

Karlsson, C. 2015. Ökad konsumtion av järn - en förutsätning för modernisering. Exemplet järnkonsumtion i medeltida åkerbruk. Järnet och Sveriges medeltida modernisering. Jernkontoret.

KLNM: Kulturhistorisk leksikon for nordisk middelalder fra vikingtid til reformasjonstid. Bind 1-20, 1956-1978. Rosenkilde og Bagger, Oslo.

Knagenhjelm, C. 2004. Kaupanger : en analyse av kaupangens lokalisering og funksjon. Upublisert hovedfagsoppgave i arkeologi, Universitetet i Bergen.

Kraft, J. 1830. Topographisk-statistisk Beskrivelse over Kongeriget Norge, Christiania.

Kristiansen, M., Gabler, M., Gustavsen, L. \& Nau, E. 2016. Georadarundersøkelse på almerket i Kinsarvik, Ullensvang kommune, Hordaland fylke. Norsk institutt for kulturminneforskning (NIKU).

Larsen, A. J. 1970. Skomaterialet fra utgravningene i Borgund på Sunnmøre 19541962, Bergen, Norwegian University Press.

Larsen, J. H. 1980. Vikingtids handelsplass i Valle, Setesdal. In: Marstrander, S. \& Johansen, Ø. K. (eds.) Festskrift til Sverre Marstrander på 70-årsdagen. Oslo: Universitetets Oldsaksamling.

Larsen, J. H. 2009. Jernvinneundersøkelser, Oslo, Kulturhistorisk museum, Universitetet i Oslo.

Larsen, J. H. \& Mjærum, A. 2014. Jernvinna i Setesdal - selvforsyning og storindustri. In: Jansen, L., Paulsen, I. \& Sundet, N. O. (eds.) Spor i Setesdalsjord. Tvedestrand: Bokbyen forlag.

Loftsgarden, K. 2015. Kolgroper - gull eller gråstein? In: Berg-Hansen, I. M. (ed.) Arkeologiske undersøkelser 2005-2006. Oslo: Portal forlag og Kulturhistoris museum.

Loftsgarden, K. 2017. Marknadsplassar omkring Hardangervidda - ein arkeologisk og historisk analyse av innlandets фkonomi og nettverk $i$ vikingtid og mellomalder. Upublisert doktorgradsavhandling i arkeologi, Universitetet i Bergen.

Loftsgarden, K., Ramstad, M. \& Stylegar, F.-A. 2017. The skeid and other assemblies in the Norwegian 'Mountain Land' In: Glørstad, Z. T. \& Loftsgarden, K. (eds.) Viking-Age Transformations: Trade, Craft and Resources in Western Scandinavia. Routledge.

Lunden, K. 2002. Frå svartedauden til 17. mai: 1350-1814, Oslo, Samlaget.

Lyngstrøm, H. 2008. Dansk jern : en kulturhistorisk analyse af fremstilling, fordeling og forbrug, København, Kongelige Nordiske Oldskriftselskab. 
Medieval Archaeology. Vol. 64, no. 1 (Pre-proof, after-review edited version)

Magnus Erlingssons saga. In: Hødnebø, F. (ed.) Snorre Sturlasons kongesagaer. Oslo: 2000. Stenersens forlag.

Magnusson, G. 1986. Lågteknisk järnhantering $i$ Jämtlands län, Stockholm, Jernkontoret.

Mikkelsen, E. 1994. Fangstprodukter $i$ vikingtidens og middelalderens фkonomi: organiseringen av massefangst av villrein $i$ Dovre, Oslo, Universitetets Oldsaksamling.

Myrdal, J. 1999. Jordbruket under feodalismen : 1000-1700, Stockholm, Natur och kultur.

Myrvoll, S. 1977. Kleberkarmaterialet fra Borgund, Sunnmøre, Bergen, Historisk museum, Universitetet i Bergen.

Narmo, L. E. 1997. Jernvinne, smie og kullproduksjon $i$ Østerdalen: arkeologiske

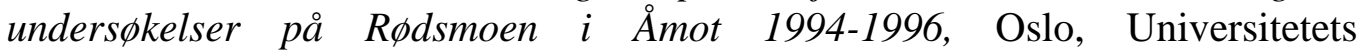
Oldsaksamling.

NgL: Norges gamle Love indtil 1387. Published by Rudolf Keyser and Peter Andreas Munch. Vol. I-V. 1846-1895. Christiania.

Nørbach, L. C. 1999. Organising Iron Production and Settlement in Northwestern Europe during the Iron Age. In: Farbech, C. \& Ringtved, J. (eds.) Settlement and Landscape. Proceedings of a Conference in Arhus, Denmark, May 4-7 1998. Højbjerg: Jutland Archaeological Society.

Orrman, E. 2003. Rural conditions. In: Helle, K. (ed.) The Cambridge History of Scandinavia. Cambridge: Cambridge University Press.

Pedersen, U. 2008. Weights and balances. In: Skre, D. (ed.) Means of exchange: dealing with silver in the Viking Age. Århus: Aarhus University Press.

Pestell, T., Ulmschneider, K. \& Sawyer, P. (eds.) 2003. Markets in early Medieval Europe: trading and 'productive' sites, 650-850, Bollington: Windgather.

Ramsey, C. B. 2017. Methods for Summarizing Radiocarbon Datasets. Radiocarbon, 59, 1809-1833.

Roland, H. 2001. Prosjekt Nordmannsslepene, Drammen, Buskerud fylkeskommune.

Ruge, H. 1916 [1750]. Thomaskyrkja paa Filefjell, Fagernes, (u.f.).

Rundberget, B. 2007. Gråfjellprosjektet, Bind 1, Jernvinna i Gråfjellområdet, Oslo, Kulturhistorisk museum, Universitetet i Oslo.

Rundberget, B. 2013. Jernets dunkle dimensjon: jernvinna i sфrlige Hedmark, sentral фkonomisk faktor og premiss for samfunnsutvikling c. AD700-1300. Upublisert doktorgradsavhandling i arkeologi, Universitetet i Oslo.

Rundberget, B. 2015. Sørskandinavisk jernutvinning i vikingtiden - lokal produksjon eller handelsprodukt? In: Pedersen, A. \& Sindbæk, S. M. (eds.) Et falles hav : Skagerrak og Kattegat i vikingetiden : seminar på Nationalmuseet, Kфbenhavn, 19.- 20. september 2012. København: Nationalmuseet.

Saga Sverris konungs: eptir gфmlum skinnbokum, 1834. Kaupmannahøfn.

Sandnes, J. \& Salvesen, H. 1978. Ødegårdstid i Norge: det nordiske фdegårdsprosjekts norske unders $\phi$ kelser, Oslo, Universitetsforlaget.

Sanmark, A. 2009. Administrative Organisation and State Formation: A Case Study of Assembly Sites in Södermanland, Sweden. Medieval Archaeology, 53, 205-241.

Schmidt, T. 2000. Marked, torg og kaupang - språkleg vitnemål om handel i middelalderen. Collegium medievale, 13, 79-102.

Sindbæk, S. M. 2005. Ruter og rutinisering : vikingetidens fjernhandel i Nordeuropa, København, Multivers Academic. 
Sindbæk, S. M. 2007a. Networks and nodal points: the emergence of towns in early Viking Age Scandinavia Antiquity, 81, 119-132.

Sindbæk, S. M. 2007b. The Small World of the Vikings: Networks in Early Medieval Communication and Exchange. Norwegian Archaeological Review, 40, 59-74.

Skre, D. (ed.) 2007. Kaupang in Skiringssal, Århus: Aarhus University Press.

Skre, D. (ed.) 2008. Means of exchange: dealing with silver in the Viking Age, Århus: Aarhus University Press.

Skre, D. (ed.) 2011. Things from the town: artefacts and inhabitants in Viking-age Kaupang, Århus: Aarhus University Press.

Skre, D. 2012. Markets, towns and currencies in Scandinavia ca. AD 200-1000. In: Gelichi, S. \& Hodges, R. (eds.) From one sea to another. Trading Places in the European and Mediterranean Early Middle Ages. Turnhout: Brepols.

Skre, D. 2013. Money and trade in Viking-Age Scandinavia. In: Bogucki, M. \& Rębkowski, M. (eds.) Economies, monetization and society in the west Slavic lands 800-1200 AD. Szczecin.

Skre, D. 2017. Monetary Practices in Early Medieval Western Scandinavia (5th-10th Centuries ad). Medieval Archaeology, 61, 277-299.

Soga om Birkebeinar og Baglar - Boglunga sogur, Oslo, 1988. Solum forlag.

Solli, B. 1999. Veøyas arkeologi. In: Solli, B., Storsletten, O. \& Sanden, J. (eds.) Veфyboka. Molde: Romsdalsmuseet.

Solli, B. \& Stamnes, A. A. 2013. Geofysiske undersøkelser av kirkegårder, kirketufter og svartjord på Veøya i Romsdal. Viking, LXXVI, 181-203.

Steen, S. 1929. Ferd og fest: reiseliv i norsk sagatid og middelalder, Oslo, Frydenlunds bryggeri.

Steinnes, A. 1930. Gamal skatteskipnad i Noreg, Oslo, I kommisjon hos Dybwad.

Stenvik, L. F. 2003. Iron production in scandinavian archaeology. Norwegian Archaeological Review, 36, 119-134.

Sverres saga, Oslo, 1979. Gyldendal.

Tveiten, O. 2012. Mellom aust og vest: ein arkeologisk analyse av jarnvinna kring Langfjella i yngre jarnalder og mellomalder. Upublisert doktorgradsavhandling i arkeologi, Universitetet i Bergen.

Tveiten, O. \& Loftsgarden, K. 2017. The extensive iron production in Norway in the tenth to thirteenth century - a regional perspective. In: Glørstad, Z. T. \& Loftsgarden, K. (eds.) Viking Age Transformations: Trade, Craft and Resources in Western Scandinavia. Routledge.

Vallevik, O. P. 1961. Grøndalsmarknaden, Hallingskeid-leikane og anna. Hardanger historielag tidsskrift.

White, L. 1964. Medieval technology and social change, London, Oxford University Press.

Øverland, O. H. 1891. Thomaskirken paa Filefjeld. Folkebladet, 4.

Øye, I. 1977. Innberetning om de arkeologiske utgravninger på Kaupanger hovedgård gnr. 105/1 Sogndal k. Sogn og Fjordane (6/6-2/7 og 26/9-6/10-1977). Middelaldersamlingen, Historisk museum.

Øye, I. 1989. Kaupangen i Sogn i komparativ belysning. Viking, LII, 21.

Øуе, I. 2002. Landbruk under press, 800-1350. Jorda blir levevei: 4000 f.Kr.-1350 e.Kr. Oslo: Samlaget. 